\title{
Estimation of the Effect of Cassava Commercialization on Different Household Income Measurements in Kilifi County, Kenya
}

\author{
Florence Opondo ${ }^{1,3}$, George Owuor ${ }^{2}$, Patience Mshenga ${ }^{2}$, Andre Louw ${ }^{3} \&$ Daniel Jordan ${ }^{3}$ \\ ${ }^{1}$ Department of Commerce, Laikipia University, Nyahururu, Kenya \\ ${ }^{2}$ Department of Agricultural Economics \& Agribusiness Management, Egerton University, Njoro, Kenya \\ ${ }^{3}$ Department of Agricultural Economics Extension and Rural Development, University of Pretoria, South Africa \\ Correspondence: Florence Opondo, Department of Commerce, Laikipia University, Nyahururu, P.O Box, \\ 1100-20300, Kenya. Tel: 254-7-2133-5299. E-mail: fopondo@laikipia.ac.ke; opondoflorence@gmail.com
}

Received: June 5, 2019

doi:10.5539/jsd.v13n1p44
Accepted: July 30, 2019 Online Published: January 30, 2020

URL: https://doi.org/10.5539/jsd.v13n1p44

\begin{abstract}
The transformation of agricultural production from subsistence to commercially oriented outcomes is a topical matter in the rural and socio-economic development discourse. Cassava crop is being promoted for commercialization because of its tolerance to harsh climatic conditions experienced in arid and semi-arid areas. Furthermore, there is high potential for the tuber crop to improve household income. In Kenya, a number of interventions have been directed towards commercializing cassava. The effect of commercialization on household income has not been established. Distinct from other studies, this study estimated the effect of cassava commercialization on three different income measures namely per capita, annual and per acre revenue. A household survey was conducted in Kilifi County in Kenya where 200 respondents were randomly selected. Data was collected using a structured questionnaire. A two-stage endogenous switching regression model was fitted to determine the effect of commercialization on the different income measures. The proportion of households that commercialized was $69 \%$ while the remaining $31 \%$ did not. The study found that majority of the households marketed low value-added cassava products. The results reveal that farmers who engaged in cassava commercialization enjoyed relatively more income than their counterparts. Off-farm income, age of the household head and distance to market had a negative significant influence in all the income estimates. Group membership was only significant for the per acre income while household size was negative and statistically significant in both per acre and per capita incomes. Findings point out the importance of promoting policies that will enhance cassava commercialization.
\end{abstract}

Keywords: commercialization, cassava, household income, estimation

\section{Introduction}

The agricultural sector is one of the drivers of the Kenyan economy with about three-quarters of the rural population depending heavily on the sector to make a living (AGRA, 2018). A significant proportion (70\%) of Kenyan land is arid and semi-arid land that is characterized by low rainfall and high temperatures. Coupled with the adverse effect of climatic change and the country's arid climate major crops such as maize and beans (FAO, 2009) tend to perform poorly. Over time, these adverse consequences have led to increased poverty levels and food insecurity (FAO, 2016). Cassava (Manihot esculenta Crantz) is one of the tuber crops that has gained prominence in Africa because of its economic importance in addressing food insecurity. It is the second most widely grown root crop in Kenya. However, the cassava sub-sector has not realized its full growth in terms of commercialization and utilization. It is evidenced that the tuber crop can enhance the food base of the poor, increase their income and mitigate poverty among rural households (FAOSTAT, 2018). This is because the crop has high yield potential with minimal input investments (Munga, maina, Muli \& Sila, 2012). Thus, production befits most rural smallholder farmers who lack adequate resources.

In Kenya, production of cassava is largely undertaken in Western, Coastal and Eastern regions. However, production is expanding to other regions such as Rift Valley and Central parts of the country (MoALFP, 2015). Western and Coastal are the major cassava growing regions in Kenya and they account for $60 \%$ and $30 \%$ of the total cassava production respectively (FAOSTAT, 2013). Moreover, Kenya has the potential to produce more 
than 2 million metric tonnes of cassava per year. This overall yield has, however, not been realized because current production of cassava is predominantly on a smallholder basis mainly for home consumption. Cassava farmers with surplus production also tend to market their produce in local markets with very little value addition. Reportedly, most of the cassava produced in Kenya is used in its raw form for human consumption or as traditional processed products through fermentation, drying and cooking (Munga et al.,2012), although, there are varied forms and uses of cassava. Several studies have been conducted on the production and improvement of cassava for food, market, and industrial uses (Muriithi \& Matz, 2015; Mutuku, Olubandwa, Malin \& Nyakeyo, 2013). The studies revealed that cassava can be transformed from a 'poor man's crop' to a high value and commercial oriented crop. Also, a number of project and program interventions have been directed to the cassava sub-sector to enhance value addition and market participation in Kenya. For instance, a National Policy on the cassava industry was developed in 2007 to address challenges related to production, marketing and regulation of the industry (MOA, 2007). The government felt that developing appropriate cassava policies could strengthen the cassava value chain hence contributing to sustainable food security, income generation and poverty mitigation. The Kenya National Federation of Agricultural Producers (KENFAP) also undertook a project on value addition and re-introduction of commercialization of cassava crops in the farm households in Kilifi County in Kenya. All these efforts have been directed at the development of the cassava industry in the country to speed up cassava commercialization.

\subsection{Concept of Commercialization}

Agricultural commercialization is a multidimensional concept with diverse meanings and theories (Zhou, Minde \& Mtigwe, 2013). Jaleta, Gebremedhin \& Hoekstra (2009) echoed that there is no standard way of gauging the degree of household commercialization hence leading to varying definitions. Varied researchers have defined the concept of commercialization differently. However, most of the prevailing opinions point towards market orientation and participation. According to Tipraqsa and Schreinemachers (2009), agricultural commercialization is the process by which farm households are integrated into both agricultural input and output markets as a pathway to improving household income. It is also a combination of decision-making behaviour ranging from production to marketing activities (Braun \& Kennedy, 1994). Dutta, Borua \& Das, (2014); Kotchikpa \& Wendkouni (2016) also argue that farm households are likely to engage in agricultural commercialization when they have product surplus.

In Kenya, most studies have concentrated on the agronomic management practices of cassava, specifically aimed at improving crop yield (Muriithi \& Matz, 2015; Mutuku et al., 2013; Karuri, Mbugua, Karugia, Wanda \& Jagwe, 2001). These studies have revealed that cassava production is limited to a few zonal areas when compared to major crops such as maize, beans and sorghum. This state of affairs has subsequently limited marketing activities for farm households to mainly at farm gates or informal markets nearby homesteads. This notwithstanding the opportunities for value addition and varied uses of cassava products which makes it a potential crop for commercialization (Mugonola, Ajok \& Ongeng, 2017; Parveen, Humaira \& Ali, 2014; Adebayo et al., 2013; Sewando, 2012).

\subsection{Components of Cassava Commercialization}

For cassava commercialization to be sustainable, product differentiation through value addition is paramount. Value addition increases income generated from commercialization activities. This is because marketing high value-added products contribute to a greater value of agricultural commercialization. It is evident that the concept of value addition as a commercialization strategy has been relatively discussed independently and not as an element of commercialization. According to Fleming (2005), value addition is a strategy that can potentially change an enterprise that is unprofitable into a profitable venture. Cassava can be marketed in various forms and the diverse products can enhance market participation, thereby creating more value which further generates more sales (Onya, Oriala, Ejiba \& Okoronkuo, 2016). Potential market opportunities exist for value-added cassava products. Therefore, the purpose of this study is to illuminate the economic importance of cassava production to households by analyzing the determinants of commercialization and the effect of commercialization on household income. The study hypothesizes that farmers who engage in commercialization are likely to earn more and especially for farm households that market high value-added cassava products (Onya et al., 2016; Dipeolo et al., 2001). Theoretically, commercialization is influenced by the behaviour of farm households in relation to the optimization of choices. The decision on whether to participate or not in commercialization is considered under the framework of utility maximization theory (Pryanishnikov and Katarina, 2016). Within this framework, commercialization decisions are measured by the gains derived from the choices that farm households make rather than the tangible benefits. These choices simultaneously influence the decision-making behavior of households. Also, economic value can be created when farm households respond to market needs with high 
value cassava products (Munga et al.,2012). Therefore, the benefits derived from the two choices (value addition and market participation) are presumed to influence commercialization decisions. This is further influenced by a number of factors.

\subsection{Factors Influencing Commercialization}

Understanding factors that influence commercialization is a way of unlocking constraints impeding the development of cassava sector. Many studies have identified influencers of commercialization (Jaleta et al., 2009; Falkowski, 2012; Martey, Ramatu \& Kowornu, 2012; Omiti, Otieno \& Nyanamba, 2009). Most importantly, limited credit facilities has been recognized as one of the constraints affecting agricultural productivity among smallholder farmers. Lerman (2004); Agwu and Ibeabuchi (2011) noted that increasing access to credit facilities could improve commercialization. Also, distance to the market is another significant determinant of cassava commercialization. Stretched distances reduce access to markets (Barrett 2008; Rios et al., 2008; Omiti et al., 2009). Notably, farm-based associations' influence the level of commercialization since it offers a solution to information asymmetry (Pigatto 2014). Other factors that have been empirically identified to influence commercialization are; gender, availability of land, extension services and market forces.

In identifying factors influencing commercialization, different methods of quantitative analysis have been applied. Agbola, Adenaike \& Babalola et al. (2010) used logit and multiple regression models to determine factors influencing farmers' access to output markets and their effects on household income. The study revealed that the cost of transportation, distance to the nearest market, access to market information and social networks influence farmers' access to output markets. Similarly, Ochieng', Knerr, Owuor \& Ouma (2015) analyzed factors that influence banana and legumes and their impact on household food security using a propensity score matching model. They observe that gender, farm size, distance to the market, education of the household head and ownership of transport equipment significantly influenced commercialization. Adenegan, Adam \& Nwauma, (2013) investigated the influence of gender on agricultural commercialization in Nigeria with regards to resource allocation. The study revealed that farm size, income and level of education in relation to gender influence commercialization.

\subsection{Literature on Commercialization}

Another strand of literature is with regard to the effect of commercialization on improving household livelihoods. Many researchers have confirmed that agricultural commercialization positively influence the livelihoods of most smallholder farmers by improving their household income and asset holdings (Hailua, Manjureb \& Aymutc, 2015; Zhou et al., 2013). In Nigeria, cassava generates the largest income for household farmers (Dipeolo et al., 2001). A research done in upland Java, Indonesia by Kowagoe (1994) found that there is a high contribution of marketing and processing of agricultural products to rural household income. The study further noted that the processing and marketing of commercial products contribute up to 70 percent of total household labour income in addition to increasing income earning opportunities. A study conducted in Kenya by Mutuku et al. (2013) examined the level of adoption of cassava commercialization in Nakuru County. It revealed that the majority of farm households' market raw cassava which attracts low price value compared to other value-added cassava products. Waswa, Mcharo \& Netando, (2009) also studied crop diversification in Nzoia and Mumias sugar belts in Kenya and their contribution towards enhancing household food and income security. The study found that cassava, sweet potatoes and other indigenous vegetables profiled as high-value crops equally have considerable potentials to generate income. From the empirical review, it is evident that cassava commercialization could significantly improve household income and livelihoods of smallholder farmers who are key players in this sub-sector. From literature, we observe that most studies related to cassava commercialization and their economic importance have been mainly conducted in West Africa.

Most studies have contextualized commercialization from a market orientation and participation point of view (Kabiti, Raidini \& Pfumayarambi, 2016; Kotchikpa and Wendkouni, 2016; Hailua et al., 2015). Notably, different studies have measured household welfare using different measurements (Mapfumo, Mushinje \& Chidoko, 2012; Mutuku et al., 2013; Chukwuji, Inoni \& Ike, 2007). In this study, we contextualized commercialization as value addition and market participation. Further, the study compares three dimensions of income estimates namely per capita, per year and per acre incomes. The annual income represents total collection for the year while per capita and per acre incomes represents measures of efficient use of resources. The use of the three alternative incomes was necessary to establish whether the different income measurements have unique elements that could lead to variations. Therefore, the study addresses factors influencing cassava commercialization in Kilifi County and the effect of commercialization on household income. 


\section{Method}

\subsection{Study Area}

The study was conducted in Kilifi County. The County lies along the coastal region of Kenya and it is mapped as ASAL area. The estimated area covered is 15,500 square kilometers. According to the Kenya National Population Census, (2009) the County has a population of 1,134,856 which include both the rural and urban inhabitants. The approximation of rural and urban population is 821,645 and 313,211 persons respectively. Kilifi County has seven administrative sub-counties namely; Kilifi North, Kilifi South, Magarini, Ganze, Rabai, Kaloleni and Malindi. The coastal region experiences an annual temperature ranging between $21^{\circ} \mathrm{C}$ to $30^{\circ} \mathrm{C}$ and an annual rainfall of between $300-1300 \mathrm{~mm}$ per annum. Importantly, the county has both arable and non-arable land estimated as $6,891 \mathrm{Km}^{2}$ and $5,407 \mathrm{Km}^{2}$ respectively. This indicates that 56 percent of the land can be utilized for agriculture. Also, majority of the farmers are smallholder farmers who practice mixed farming. Therefore, agriculture is one of the dominant occupations of the people in the region. It is also worth noting that Kilifi is one of the tourist attraction regions because of its coastal location. Despite the prevalent opportunities, poverty levels in the region are high with 68 percent of the population living below the poverty.

\subsection{Data Collection and Analysis}

Data was collected through a household survey which was conducted between May and June 2015. A four-stage sampling technique was employed to sample farmers from Kilifi County. In the first stage, Magarini and Ganze constituencies were purposively selected. This was informed by the high productivity of cassava in the areas. The second stage involved random sampling of two locations from each sub-county and in the third stage five villages were randomly selected from the locations. Finally, systematic samples of ten farm households who had engaged in cassava production were selected. This method was applicable because of the missing sampling frame of farmers who grow cassava in each village. A total of 200 households were sampled for the study. A well-structured questionnaire was used for data collection. Data collection tool was divided into two major sections. The first section contained demographic information while in the second section, a collection of questions on; farmers' household characteristics, land ownership and use, asset ownership, labor distribution, production and value addition aspects of cassava, institutional and marketing factors as well as household income were considered.

\subsection{Method of Analysis}

This study aimed at establishing the effect of cassava commercialization on household income. Household welfare is a multidimensional theory; therefore, we attempt to understand the different dynamics by comparing the different income measurements. World Bank (1998) identified three methods of estimating the household welfare. Hailua et al., (2015) also explored different approaches used to measure household welfare. The study concludes that income can be justifiably used as a unit of measure. Brewer \& O'Dea (2017), Tambo \& Wunscher (2014) also supported the use of income as a measure of household welfare and recommended per capita income as the most appropriate. In this study, three different income estimates mainly; per capita income, average income per household per year and average income per acre were used. The assumption made is that farmers' decision on commercialization is endogenous to household income and therefore certain unobserved individualities may influence the decision on whether to commercialize or not. We therefore fitted an endogenous switching model. The model accounts for the association between unobserved characteristics in participating in cassava commercialization and improved household welfare through income. As seen earlier, the endogenous model is supported by full information maximum likelihood estimation (FIML) which corrects biasness in the household income estimates. We analyzed the determinants of cassava commercialization in the first stage of endogenous switching regression model. This involved an estimation of the selection equation using the probit model. Diagnostic tests such as multicollinearity and heteroskedasticity tests were performed in evaluating the model. Multicollinearity test was based on variance inflation factor (VIF) while heteroskedasticity test was also performed using the Breuche-Pagan test. The results revealed that there were no cases of multicollinearity and heteroskedasticity. In addition, the diagnostic tests confirmed that the estimated coefficients of the two instrumental variables (group membership and distance to the market) were jointly insignificant $(p>0.10)$ in the income equation. However, the variables were significant in the commercialization equation. This indicated that the instrumental variables were valid. The first stage equation is presented as follows:

$$
A^{*}{ }_{i}=Z_{i} \alpha+\mu_{i}
$$

Where 


$$
\mathrm{A}_{i}=1 \text { if } \quad A^{*}{ }_{i}>0 \quad \text { commercialize }
$$

$$
\mathrm{A}_{i}=0 \text { if } A^{*}{ }_{i}<0 \text { otherwise, do not commercialize }
$$

In the above equation, $\mathrm{A}^{*}{ }_{i}$ Represents the unobservable or latent variable for commercialization, while $\mathrm{A}_{\mathrm{i}}$ is the observable counterpart. The latter shows whether a farm household was involved in cassava commercialization or not. Conversely, $Z$ represents the vectors of observed characteristics that affect commercialization while ${ }^{i}$ represents cassava farm households and $\mu_{i}$ denote the stochastic disturbances. Also, $A^{*}$ represents the net utility derived from cassava commercialization which is unobservable. Measuring the amount of net utility derived from the decision to commercialize is hardly possible. However, one is capable of making an observation on the actual outcome. In this case, the predicted probability obtained from the first stage equation was used in the second stage to obtain estimates of cassava commercialization. The aforementioned instrumental variables were controlled in the joint equation. Three different income estimates were modeled as the dependent variable. The stage-two estimation model is defined as follows:

$$
\begin{array}{llll}
\text { Regime1 } & \gamma_{1 i}=\beta_{1} \chi_{1 i}+e_{1 i} & \text { if } & G_{i}=1 \\
\text { Regime2 } & \gamma_{2 i}=\beta_{2} \chi_{2 i}+e_{2 i} & \text { if } & G_{i}=0
\end{array}
$$

Where $y_{1 i}$ and $y_{2 i}$ represents the household income in regimes 1 and 2 while $\chi_{1 i}$ and $\chi_{2 i}$ represents vectors of exogenous variables that are thought to influence income. Additionally, $G_{i}=1$ and $G_{i}=0$ denote the commercialized and non-commercialized groups respectively. The model assumes that for endogeneity to be present, there must exist a trivariate normal distribution between the error terms and the zero- mean vector. This is specified in the covariance matrix shown below;

$$
\operatorname{COV}\left(e_{1 i}, e_{2 i}, u_{i}\right)=\left(\begin{array}{lll}
\sigma_{e 2}^{2} & \bullet & \sigma_{e 2 u} \\
\bullet & \sigma_{e 1}^{2} & \sigma^{1} u \\
\bullet & \bullet & \sigma_{u}^{2}
\end{array}\right)
$$

Where $\sigma^{2}{ }_{e 2}$ presents a variance of the error term in the selection equation (1) and it is assigned to status 1 while $\sigma_{e 1}^{2}$ and $\sigma_{\mu}^{2}$ shows the variances of the error terms in the income equations ( $2 \mathrm{a}$ and $2 \mathrm{~b}$ ). Also $\sigma_{\mu}^{1}$ is a covariance of $\mu_{i} e 1_{i}$ while $\sigma^{2}{ }_{\mu}$ is the covariance of $\mu_{i}$ and $e 2_{i}$. It is assumed that the error terms have a trivariate normal distribution with a mean vector zero as aforementioned. The estimated co-variances were found to be statistically significant hence the decision to commercialize and the household income were correlated. This justifies the appropriateness of endogenous switching model. Hence, the null hypothesis of sample 
selectivity bias will be rejected. This model has been widely used by researchers. For instance, Di Falco, Veronesi \& Yesuf (2010) used the model to assess the adoption to climate in response to food security in Ethiopia. Kim, Mayga \& Capps (2000) similarly applied the model in assessing the effects of consumer label use on nutrient intake.

\section{Results and Discussion}

\subsection{Descriptive Statistics of Farm Households Characteristics}

A number of factors that influence cassava commercialization subsequently affecting household income were empirically identified. The descriptive statistics for the specific variables fitted in the model are as summarized in Table 1.

Table 1. Descriptive statistics of continuous variables fitted in endogenous switching model

\begin{tabular}{|c|c|c|c|c|c|}
\hline \multirow[b]{2}{*}{ Variables } & \multicolumn{2}{|c|}{ Commercialized (138) } & \multicolumn{2}{|c|}{ Non-Commercialized (62) } & \multirow{2}{*}{$\begin{array}{l}\text { Difference in } \\
\text { means }\end{array}$} \\
\hline & Mean & Std. Dev. & Mean & Std. Dev. & \\
\hline \multicolumn{6}{|l|}{ Dependent variables } \\
\hline Annual household income (Kes) & 53555.12 & 89484.93 & 38431.45 & 58532.37 & -1.218 \\
\hline Per Capita Income (Kes) & 11056.81 & 222161.98 & 6354.19 & 10016.11 & -1.591 \\
\hline Per Acreage Income (Kes) & 10769.26 & 21863.53 & 8906.87 & 15338.05 & -0.607 \\
\hline \multicolumn{6}{|l|}{ Independent variables } \\
\hline Age (Years) & 45.89 & 12.65 & 44.76 & 10.31 & -0.622 \\
\hline Education (Years) & 4.55 & 4.37 & 3.90 & 4.29 & -0.975 \\
\hline Household size (Number.) & 7.17 & 3.59 & 7.42 & 2.88 & 0.474 \\
\hline Value addition experience (Years) & 10.42 & 9.25 & 10.69 & 10.14 & 0.187 \\
\hline Farm size (Acreage) & 7.71 & 6.97 & 6.69 & 7.02 & -0.958 \\
\hline Distance to market $(\mathrm{Km})$ & 0.15 & 0.32 & 0.84 & 0.69 & $-7.557 * * *$ \\
\hline
\end{tabular}

$* * * *$ denotes statistically significant at $1 \%$

As indicated in Table 1, $69 \%$ of the farm households engaged in commercialization activities while $31 \%$ did not. Notably, there is a difference in the means for the different income measurements for the two regimes. Farm households that commercialized earned more than the non-commercialized group in all the income indicators. This could be attributed to the significant variations in the sizes of land as well as the acreage under cassava production. We also see slight variations in other variables for the two regimes. However, the variations are not highly significant. Other than the continuous variables, we also fitted five categorical variables in the model. A summary statistic of the variables is presented in Table 2 . 
Table 2. Descriptive statistics of categorical variables used in the model

\begin{tabular}{lllll}
\hline Categorical variables & Commercialized (\%) & Non-Commercialized (\%) & \multicolumn{2}{c}{$\chi^{2}$ value } \\
\hline Gender & Female & 72.46 & 66.12 & $0.096^{*}$ \\
& Male & 27.54 & 33.88 & \\
Off-farm income & Yes & 45.65 & 35.48 & 0.179 \\
& No & 54.35 & 64.52 & \\
Access to credit & Yes & 33.33 & 45.16 & $0.091^{*}$ \\
& No & 66.67 & 54.84 & \\
Group membership & Yes & 78.99 & 80.65 & $0.072^{*}$ \\
& No & 21.01 & 19.35 & \\
Remittances & Yes & 31.88 & 27.41 & 0.526 \\
& No & 68.12 & 72.59 & \\
\hline
\end{tabular}

Table 2 reveals that gender, access to credit and group membership were statistically significant $(\mathrm{P}=0.1)$. It is clear from the table that majority $(72.46 \%)$ of those who participated in cassava commercialization are female headed households. Traditionally, women are actively involved in small-scale farming as men spend most of their time in off-farm activities to earn extra income (Woldeyohanes, Heckelei \& Surry, 2015). The gender differential has an influence on decision making process on farming activities. The study further shows that the proportion of those who engaged in off-farm activities is $45.65 \%$ for the commercialized and $35.48 \%$ for those who had not commercialized. It is evidenced that $33.33 \%$ of farm households who commercialized received some form of credit facilities while the majority $(66.67 \%)$ did not. Access to credit facilities is important as it helps link farmers with modern technology thus enhancing their abilities and knowledge in farming activities (Lerman, 2004). Group membership is equally important since it can be a source of information and technologies that can enhance market opportunities. The results further illustrate that the average of remittance is $42 \%$ and $23 \%$ for the commercialized and non-commercialized groups respectively. In overall, a small proportion (31.88\%) of farm households received substantial income from remittances. Past studies have revealed that remittance has a mixed effect on commercialization. Quinn (2009) argues that the inflow of remittances to farm households can boost farm inputs and asset purchases. Other studies have also found that remittances negatively contribute towards commercialization as overreliance on it limits undertaking agricultural activities (Woldeyohanes et al., 2015). The mixed outcome was therefore expected from the study as far as remittance is concerned. This could be supported by the expected utility maximization theory which argues that households make choices that yield the highest expected utility.

\subsection{Results of Endogenous Switching Model}

\subsubsection{Determinant of Cassava Commercialization}

In this section, we, first present the results on the determinants of cassava commercialization analyzed by estimating the selection equation using the probit model. This is clearly presented in Table 3 . We then discuss positive factors followed by the negative factors that influence commercialization. The econometric results indicate that group membership was positive and only significant for the per acre income model; that is, group membership influenced farm households' that engaged in cassava commercialization activities. As discussed earlier, groups open up opportunities to output markets through collective bargaining for appropriate prices resource mobilization and access to relevant information and technology (Magreta et al., 2010). In addition, farm households are able to acquire skills through knowledge exchange when they freely interact with members of a similar social network. This finding is supported by the qualitative evidence that was gathered during fieldwork. Other studies have also recognized the importance of group networks in accelerating agricultural activities (Mwaura, 2014; Olwande \& Mathenge 2010). 
Table 3. Probit model on determinants of cassava commercialization

\begin{tabular}{|c|c|c|c|c|}
\hline \multirow[b]{4}{*}{ Variables } & \multicolumn{3}{|c|}{ Jointly Estimated } & \multirow{3}{*}{ Independent Estimated Probit } \\
\hline & Probit & & & \\
\hline & Per acre & Per Capita & Yearly Inc. & \\
\hline & Estimates & Estimates & Estimates & Coef. \\
\hline \multirow{3}{*}{$\begin{array}{l}\text { Education (Years of } \\
\text { schooling) }\end{array}$} & 0.075 & 0.062 & 0.113 & 0.109 \\
\hline & $(0.391)$ & $(0.429)$ & $(0.276)$ & $(0.284)$ \\
\hline & -0.044 & -0.033 & 0.068 & 0.067 \\
\hline \multirow[t]{2}{*}{ Value addition Experience (Years) } & $(0.629)$ & $(0.715)$ & $(0.551)$ & $(0.556)$ \\
\hline & $-0.286^{*}$ & $-0.313^{*}$ & -0.299 & -0.298 \\
\hline \multirow[t]{2}{*}{ Household size (Numbers) } & $(0.041)$ & $(0.063)$ & $(0.143)$ & $(0.141)$ \\
\hline & 0.007 & 0.044 & 0.194 & 0.194 \\
\hline \multirow[t]{2}{*}{ Farm size (Acres) } & $(0.939)$ & $(0.692)$ & $(0.126)$ & $(0.126)$ \\
\hline & $-0.736 * * *$ & $-0.753 * * *$ & $-0.356^{*}$ & $-0.359 *$ \\
\hline \multirow[t]{2}{*}{ Off-farm income (Kes) } & $(0.000)$ & $(0.000)$ & $(0.083)$ & $(0.080)$ \\
\hline & -0.008 & -0.007 & -0.328 & -0.322 \\
\hline \multirow[t]{2}{*}{ Gender ( $1=$ Male, $0=$ Female $)$} & $(0.967)$ & $(0.967)$ & $(0.137)$ & $(0.138)$ \\
\hline & $-0.405 * *$ & $-0.412 * *$ & $-0.538 * *$ & $-0.539 * *$ \\
\hline \multirow[t]{2}{*}{ Age (Years) } & $(0.025)$ & $(0.021)$ & $(0.015)$ & $(0.015)$ \\
\hline & -0.063 & -0.083 & 0.271 & 0.267 \\
\hline \multirow[t]{2}{*}{ Receive remittance $(1=$ Yes, $0=$ No $)$} & $(0.707)$ & $(0.172)$ & $(0.220)$ & $(0.223)$ \\
\hline & $0.106^{* * *}$ & 0.107 & -0.241 & -0.242 \\
\hline \multirow[t]{2}{*}{ Group membership $(1=$ Yes, $0=$ No $)$} & $(0.000)$ & $(0.647)$ & $(0.345)$ & $(0.253)$ \\
\hline & $-0.236 * * *$ & $-0.244 *$ & $-0.454 * * *$ & $-0.455 * * *$ \\
\hline \multirow[t]{2}{*}{ Distance to market $(\mathrm{Km})$} & $(0.000)$ & $(0.092)$ & $(0.004)$ & $(0.004)$ \\
\hline & 1.335 & 1.345 & 1.000 & 1.009 \\
\hline cons & $(0.001)$ & $(0.003)$ & $(0.079)$ & $(0.571)$ \\
\hline No. of observations & 200 & 200 & 200 & 200 \\
\hline Prob $>$ chi-squared & & & & 0.006 \\
\hline Pseudo $\mathrm{R}^{2}$ & & & & 0.098 \\
\hline LR chi2 (10) & & & & $24.43 * * *$ \\
\hline \multirow{2}{*}{$\chi^{2}-$ Statistic for over identification } & & & & 0.533 \\
\hline & & & & 0.383 \\
\hline
\end{tabular}

Figures in parenthesis are the p-values. ${ }^{* *},{ }^{* *}$ and $*$ represent significance levels at $1 \%, 5 \%$ and $10 \%$ respectively

With respect to off-farm income, we found that the income had a negative and significant influence on cassava commercialization across all the models. This suggests that off-farm activities demand a lot of time and this limits involvement in commercialization activities Also, those who have prioritized commercialization may not have time to undertake off-farm activities and vice versa. Overall, this understanding is in agreement with the finding of Muricho (2015) who reported that off-farm income lowers the incentive to commercialize.

Age of the household head was also found to be negative and significant across all the models. This implies that ageing reduces the likelihood of engaging in commercialization, more so, beyond maturity age (50 years and above). Generally, productivity declines as farmers get older. This reduces active engagement in commercialization activities. This finding is consistent with that of Agbola et al. (2010) who found that as 
household heads advance in age, they influence households to engage in basic farming activities and spend less time on commercialization activities such as value addition and market participation. The study however, contradicts the findings of Hailua et al. (2015) who found a positive relationship between age and commercialization. They argued that age being a proxy of farming experience, increases commercialization since older household heads have more insights and adequate knowledge that can accelerate market activities.

Distance to the market is a key determinant of commercialization. In this study, distance to the nearest market had a negatively significant influence on cassava commercialization across all the three models. Farmers distanced from market centers are less likely to commercialize. The reason could be that most rural transportation networks are not properly linked to the villages where majority of the farm households populate. In addition, most of the rural roads are in a poor state and this limits movements. This therefore, increases transaction costs hence lowering the intensity of market participation (Pingali, Khwaja \& Meijer, 2005). Research has further shown that an increase in transport costs reduces the likelihood of participation in commercialization (Ochieng' et. al., 2015; Omiti, 2009; Barret, 2008).

\subsubsection{Effect of Cassava Commercialization on Household Income}

In the second stage of endogenous model, we analyzed the effect of cassava commercialization on household income. We first performed diagnostic tests to determine the robustness of the model. Table 4 shows that the likelihood ratio tests (LR) for the joint independence of the three equations were significant in the two groups. This means that the selection and income equations are jointly dependent hence providing evidence of endogeneity. However, the coefficient for the non-commercialized group was negative for the per capita model further indicating the existence of endogeneity. Though it was expected that all the models would give similar results, the variations can be explained by the fact that there are unique variations in the different income measurements. This further justifies our concern in using the different income measurements. The results also show that the coefficients of variance of the error terms are positive and significant $(1.112,1.092,1.039)$ supporting our hypothesis that cassava commercialization affects household income. This suggests that farm households that engaged in commercialization activities had an improved income compared to their counterparts. 
Table 4. Results of endogenous switching model on the effect of cassava commercialization on household income

\begin{tabular}{|c|c|c|c|c|c|c|}
\hline \multirow[b]{2}{*}{ Variables } & \multicolumn{2}{|c|}{ Commercialization $(\mathrm{n}=138)$} & \multicolumn{4}{|c|}{ Non-Commercialization $(\mathrm{n}=62)$} \\
\hline & $\begin{array}{r}\text { Per Acre. } \\
\text { Coef. }\end{array}$ & $\begin{array}{l}\text { Per Capita } \\
\text { Coef. }\end{array}$ & $\begin{array}{r}\text { Per yr. } \\
\text { Coef } \\
\end{array}$ & $\begin{array}{r}\text { Per Acre. } \\
\text { Coef. }\end{array}$ & $\begin{array}{c}\text { Per Capita. } \\
\text { Coef. }\end{array}$ & $\begin{array}{r}\text { Per Yr. } \\
\text { Coef. }\end{array}$ \\
\hline Education (Years of & 0.000 & 0.046 & 0.142 & -0.012 & -0.018 & -0.012 \\
\hline \multirow[t]{2}{*}{ Schooling) } & $(0.998)$ & $(0.846)$ & $(0.590)$ & $(0.975)$ & $(0.960)$ & $(0.980)$ \\
\hline & 0.276 & 0.238 & $0.475^{*}$ & 0.341 & 0.316 & 0.404 \\
\hline \multirow[t]{2}{*}{ Value addition Experience } & $(0.318)$ & $(0.367)$ & $(0.097)$ & $(0.401)$ & $(0.422)$ & $(0.403)$ \\
\hline & 0.000 & $-0.947 * *$ & -0.316 & -0.569 & -0.384 & -0.797 \\
\hline \multirow[t]{2}{*}{ Household size } & $(0.999)$ & $(0.020)$ & $(0.465)$ & $(0.584)$ & $(0.178)$ & $(0.513)$ \\
\hline & $-0.604 * *$ & 0.287 & $0.789^{* *}$ & $-0.898 *$ & -0.073 & -0.096 \\
\hline \multirow[t]{2}{*}{ Farm size } & $(0.041)$ & $(0.327)$ & $(0.016)$ & $(0.051)$ & $(0.873)$ & $(0.889)$ \\
\hline & -0.068 & -0.006 & 0.579 & $2.573^{* * *}$ & $2.309^{* * *}$ & $3.157^{* * *}$ \\
\hline \multirow[t]{2}{*}{ Remittance } & $(0.896)$ & $(0.991)$ & $(0.282)$ & $(0.002)$ & $(0.004)$ & $(0.003)$ \\
\hline & $3.251 * * *$ & $3.233^{* * *}$ & $3.888^{* * *}$ & $5.496^{* * *}$ & $5.257 * * *$ & $6.399 * * *$ \\
\hline \multirow[t]{2}{*}{ Off-farm income } & $(0.000)$ & $(0.000)$ & $(0.000)$ & $(0.000)$ & $(0.000)$ & $(0.000)$ \\
\hline & 0.747 & 0.748 & 0.125 & 0.628 & 0.733 & 0.738 \\
\hline \multirow[t]{2}{*}{ Gender } & $(0.184)$ & $(0.145)$ & $(0.825)$ & $(0.402)$ & $(0.318)$ & $(0.443)$ \\
\hline & 0.385 & 0.369 & -0.547 & -0.186 & -0.155 & -0.375 \\
\hline \multirow[t]{2}{*}{ Age cat3 } & $(0.514)$ & $(0.477)$ & $(0.390)$ & $(0.851)$ & $(0.873)$ & $(0.778)$ \\
\hline & 7.218 & 7.317 & 5.119 & 3.820 & 4.0771 & 3.740 \\
\hline _cons & $(0.000)$ & $(0.000)$ & $(0.000)$ & $(0.406)$ & $(0.357)$ & $(0.384)$ \\
\hline \multirow{2}{*}{$\operatorname{In} \sigma_{\mu_{1}} v$} & $1.112^{* * *}$ & $1.092 * * *$ & $1.039 * * *$ & & & \\
\hline & $(0.000)$ & $(0.000)$ & $(0.000)$ & & & \\
\hline \multirow{2}{*}{$\rho_{\mu_{i}} v$} & & & & -11.096 & $-0.845^{* * *}$ & 0.047 \\
\hline & & & & $(0.142)$ & $(0.001)$ & $(0.416)$ \\
\hline \multirow[t]{2}{*}{$\operatorname{In} \sigma_{\mu_{0}} v$} & $1.006 * * *$ & $0.983^{* * *}$ & $1.186^{* * *}$ & & & \\
\hline & $(0.000)$ & $(0.000)$ & $(0.000)$ & & & \\
\hline \multirow{2}{*}{$\rho_{\mu_{0}} v$} & & & & 0.089 & 0.003 & 0.214 \\
\hline & & & & $(0.912)$ & $(0.995)$ & $(0.787)$ \\
\hline LR test of indep. equations & 0.000 & 0.000 & 0.763 & & & \\
\hline Log-Likelihood & & & & -549.753 & -544.289 & -611.322 \\
\hline
\end{tabular}

Note: The income equation was jointly estimated with the equation on cassava commercialization $\sigma_{\mu_{1}}$ represents the square root of the variance of the error terms while $\rho_{\mu_{i}}$ represent the correlation coefficients of the error terms of the selection and outcome equations. Significant at $1 \%$, $* *$ significant at $5 \%,{ }^{*}$ significant at $10 \%$.

With regard to the significant variables, there were mixed outcomes more so in the direction of the coefficients. Value addition experience is positive and significant only in the annual income model for the households that commercialized. This means that an increase in value-addition experience of a household head is associated with improved household income. We argue that since annual income is recorded over a year period, it is a function of time. It is possible that over a period, a farmer can gain experience that may affect farm productivity as well as market choices. The finding is consistent with that of Kehinde \& Aboaba (2016) who found that value addition techniques enhanced through training and experience can promote efficiencies and diversification thereby increasing household income. This finding is in accord with other studies which have noted that experience 
enables farmers to engage in agricultural commercialization (Parveen et al., 2014; Agwu, 2012). In the case of other sources of income, off-farm income has a positive and significant influence on the different income measurements in all the models. The results indicate that farm households who undertake off-farm activities have higher household income than those who do not. However, we find that for the non-commercialized group, the sizes of the coefficients are larger than for their counterparts. This could mean that such households have concentrated their energy and resources on off-farm activities unlike farm households who had commercialized.

Table 4 shows that the coefficients for off-farm income are different in magnitude. For annual income, the coefficients are larger than the ones for per capita and acre. We argue that annual income has a higher value because the per capita and per acre incomes are computed averages. The incomes are explained by the same independent variable of which variations are expected. Concerning remittance, the results show a positive and significant influence on the different income measurements only for the non-commercialized households. This suggests that household income is higher for those who received remittances but did not commercialize than those who received remittances and did commercialize. This is in agreement with the findings of Xing (2015) who opines that remittance has a direct influence on household income. According to Leones \& Feldman (1998), remittance is also recognized as a resource diversification strategy and it relaxes the constraint on household income amongst smallholder farmers. The insignificance of remittance amongst the commercialized group makes sense since those who are involved in commercialization activities are not highly dependent on remittances because they also earn significant income from cassava commercialization.

We then discuss variables that negatively influenced household income. Household size negatively and significantly influenced household per capita income for the farm households that commercialized. The negative relationship indicates that farmers with larger household size have less household per capita income. This result is inconsistent with the finding of Effiong (2005) who stated that large households can enhance the availability of farm labour hence lowering the cost of production. A household that is composed of mature working adults will have better household income than a farm household composed of young, uneconomically and unproductive children (Bongaarts, 2001). Farm size, on the other hand, has mixed outcomes for the different income measurements. It is positive and significantly related to the annual income model for the commercialized group. However, it has a negative relationship with the income per acre model for the commercialized and non-commercialized groups. The positive coefficient of farm size variable in the annual income model supports the view that large farm size is an incentive to production of marketed surplus. This can significantly accelerate commercialization. In addition, smallholder farmers with large farm sizes can improve their household income through a varied portfolio of activities (Adams, 2002). The negative coefficient in the income per acre model suggests that farmers with large acreage earn less average income per acre than those who have small acreage. It can be further argued that most smallholder farmers operate on a low scale and they may not have adequate resources required to manage large parcels of land efficiently. Hence, farmers with small acreage of land are likely to fully optimize the available resources resulting in higher income per acre.

\section{Conclusion}

This study underscores the role of cassava commercialization on household income in Kilifi County, Kenya. This is one of the counties that has received initiatives from different organizations to stimulate the growth of cassava sub-sector and promote commercialization. The initiatives have been envisioned to improve household welfare. This study contributes to this argument by estimating the effect of cassava commercialization on different income estimates. Two concepts namely; value addition and market participation were considered in defining commercialization since agricultural commercialization takes various forms. Additionally, three different household income measurements were compared in this study. They include; per capita, per acre and annual incomes. A two-stage endogenous regression model was fitted. The first stage involved the identification of determinants of cassava commercialization. In the second stage we tested the effect of commercialization on household income. The study finds that farm households that engage in commercialization typically enjoy improved household income unlike their counterparts. This reveals that farmers who commercialize are better off than those who do not commercialize in terms of income. The finding is consistent with other studies that have addressed the effect of agricultural commercialization on household income (Hailua et al., 2015 and Dipeleo et al.,2001). The results reveal that off-farm income, age and distance to the market have a negative influence on commercialization in the two models. The effect of farm size varies in the two regimes. However, off-farm income is significant across the groups even though the coefficients for the non-commercialized group are greater than for their counterparts. Remittances was significantly positive for the non-commercialized group further indicating that the non-commercialized households rely on remittance and off-farm income predominantly. Household size was also found to negatively influence household income for the commercialized 
group. Household size intuitively is likely to directly affect the marketable surplus of a cassava crop. No major observations are made on the variation of the variables across the different income estimates. It is noted that the coefficients for annual income is greater than per acre and per capita measurements. It is also argued that annual income is measured over a period unlike the other incomes that are averages hence the difference is expected. The study recommends that farmers should market high value cassava products to increase the economic opportunities of cassava commercialization. The County government should offer support mechanisms that can enhance market competitiveness through cassava commercialization. These include, improving infrastructure especially road networks to facilitate easy access to markets, training farmers on the importance of collective actions through extension services. Finally, we recommend that a comprehensive study to be undertaken to determine the extent to which off-farm activities affect cassava commercialization.

\section{Acknowledgments}

German Academic Exchange Service (DAAD) financially supported this work. We are grateful to the organization for the support, which facilitated the research work. Appreciation to the Centre of Excellence in Sustainable Agriculture and Agribusiness Management (CESAAM), Egerton University and the team members for offering assistance during the study period. We would also like to extend our thanks to the field assistants and farm households for their participation in this research. Lastly, our thanks go to all individuals who interacted with the work and offered valuable comments.

\section{References}

Adams, R. H. (2002). Non-farm income, land and inequality in rural Egypt. Economic Development and Cultural Change, 50(2), 339-363. https://dx.doi.org/10.1086/321913

Adebayo, B., Abass, N. M., Roger, R., Monde, Z., Ivor, M., Abele, S. ... Cromme, N. (2013). Potential for commercial production and marketing of cassava: experiences from the small-scale cassava processing project in East and Southern Africa. IITA, Ibadan, Nigeria.

Adenegan, K., Adams, O., \& Nwauwa, L. (2013). Gender impacts of small-scale farm households on agricultural commercialisation in Oyo State, Nigeria. Journal of Economics Management and Trade, 3(1), 1-11. https://doi.org/10.9734/bjemt/2013/1910.

Agbola, P. O., Adenaike, T., \& Babalola, D. A. (2010). Determinants of farmers' access to output markets and the effects on income; A case study of Ikenne local government area, Nigeria. Journal of Life and Physical Sciences, 3(2), 33-39.

AGRA. (2018). Africa Agriculture Status Report: Catalyzing government capacity to drive agricultural transformation (Issue 6). Nairobi, Kenya: Alliance for a Green Revolution in Africa (AGRA).

Agwu, N., \& Ibeabuchi, J. (2011). Socio-economic analysis of wholesale rice marketers in Abia State, Nigeria. International Journal of Social Science and Humanity, 1(4), 285-288. https://doi.org/10.7763/ijssh.2011.v1.52

Agwu, N. (2012). Determinants of profitability among plantain marketers in Abia State, Nigeria. The Nigerian Journal of Development Studies, 7(1), 49- 58.

Barrett, C. (2008). Smallholder market participation: Concepts and evidence from eastern and Southern Africa. Journal of Food Policy, 33(4), 299-317. https://doi.org/10.1016/j.foodpol.2019.7.21

Bongaarts, J (2001). Household size and composition in the developing world in the 1990s. Population Studies. $A$ Journal of Population studies, 55(3), 263-279. https://doi.org/10.1080/00324720127697

Braun, V. J., \& Kennedy, E. T. (1994). Agricultural commercialization, economic development, and nutrition. Baltimore, MD: Published for the International Food Policy Research Institute (IFPRI) by Johns Hopkins University Press.

Brewer, M., \& O'Dea. C. (2017). Why are households that report the lowest incomes so well-off? The Economic Journal, 127(605), 24-49. https://doi.org/10.1111/ecoj.12334

Chukwuji, C. O., Inoni, O. E., \& Ike, P. C. (2007). Determinants of technical efficiency in gari processing in Delta State, Nigeria. Journal of Central European Agriculture, 8(3), 327-336.

Dutta, J., Boruah, R., \& Das, S. (2014). Measuring the level of commercialization of farmers: A Case in the Kamrup District of Assam. Indian Research Journal of Extension Education, 15(1), 35-39. 
Effiong, E. O. (2005). Efficiency of production in selected livestock Enterprises in Akwa-Ibom State, Nigeria. Published PhD. Thesis, Department of Agricultural Economics, Michael Okpara University of Agriculture, Umudike. http://doi.org/10.5539/ibr.v7n12p128

Falkowski. (2012). Does farm and processing industry structure matter for price transmission? Some evidence from transition countries: A Comparison of dairy sectors in hungary and Poland. Discussion papers, Institute of Economics, Centre for Economic and Regional Studies, Hungarian Academy of Sciences, No 1212, IEHAS. http://hdl.handle.net/10419/108266

FAO. (2016). The state of food and agriculture: Climate change, agriculture and food security, Rome. Retrieved from www.fao.org/publications/sofa/2016/en

FAO. (2009). Development of cassava processing industry and its future. Food and Agriculture Organization, Rome.

FAOSTAT. (2018). The State of food security and nutrition in the world 2018. Building climate resilience for food security and nutrition. Rome, FAO. Retrieved from www.fao.org/3/i9553en/19553en.pdf

FAOSTAT. (2013). Food and Agriculture Organization of the United Nations, statistics centre, Nicaraguan cassava production quantities.

Fleming, K. (2005). Value-added strategies:Taking agricultural products to the next level Value-Added Strategies: Cooperative Extension Service, College of Tropical Agriculture and Human Resources, University of Hawaii Manoa. AB-16.

Hailua, G., Manjureb, K., \& Aymutc, K (2015). Crop commercialization and smallholder farmers livelihood in Tigray region, Ethiopia. Journal of Development and Agricultural Economics, 7(9), 314-322. https://doi.org/ 10.5897/jdae.2015.0649

Jaleta, M., Gebremedhin, B., \& Hoekstra, D. (2009). Smallholder Commercialization: Processes, Determinants and Impact. Discussion Paper No. 18. Improving productivity and market success (IPMS) of Ethiopian farmers project, ILRI, Nairobi, Kenya. 55pp.

Kabiti, H. M., Raidimi, N. E., Pfumayaramba, T. K., \& Chauke, P. K. (2016). Determinants of agricultural commercialization among smallholder farmers in Munyati resettlement area, Chikomba District, Zimbabwe. Journal of Human Ecology, 53(1), 10-19. https://doi.org/10.1080/09709274.2016.11906951

Karuri, E. E., Mbugua, S. K., Karugia, J., Wanda, K., \& Jagwe, J. (2001). Marketing opportunities for cassava-based products: An assessment of the industrial potential in Kenya. Journal of Animal and Plant Sciences, 2(2), 76-84

Kehinde, A. L., \& Aboaba, K. O. (2016). Analysis of value addition in the processing of cassava tubers to "garri" among cottage level processors in southwestern Nigeria. Paper presented at the 5th International Conference of the African Association of Agricultural Economists, Addis Ababa, Ethiopia.

Kim, S.-Y., Nayga, R. M. Jr., \& Capps, O. Jr. (2000). The effect of food label use on nutrient intakes: an endogenous switching regression analysis. Journal of Agricultural and Resource. Economics, 25(1), 21-31.

Kotchikpa, G. L., \& Wendkouni, J.-B. Z. (2016). Factors influencing smallholder crop commercialization: Evidence from Cte d'Ivoire. African Journal of Agricultural Research, 11(41), 4128-4140.https://doi.org/10.5897/ajar.2016.11553

Lerman, Z. (2004). Policies and institutions for commercialization of subsistence farms in transition countries. Journal of Asian Economics, 15, 461-479. https://doi.org/10.1016/j.asieco.2004.05.004

Leones, J., \& Feldman, S. (1998). Non-farm activity and rural household income: Evidence from Philippine Microdata. Journal of Economic Development and Cultural Change, 46(4), 789-806.

Mapfumo, A., Mushunje, A., \& Chidoko, C. (2012). The impact of Government agriculture expenditure on poverty in Zimbabwe. Russian Journal of Agricultural and Socio-Economic Sciences, 7(7), 16-22. https://doi.org/10.18551/rjoas.2012-07.03

Martey, M., Ramatu, M. A.-H., \& Kuwornu, J. K. M. (2012). Commercialization of smallholder agriculture in Ghana: A Tobit regression analysis. African Journal of Agricultural Research, 7(14), 2131-2141. https://doi.org/10.5897/ajar.11.1743

MOA. (2007). Republic of Kenya, report by Ministry of agriculture, National Policy on Cassava Industry Policy Reforms to improve production, research, marketing and regulation in the cassava industry. 
MOALF. (2015). Agricultural Sector Development Support Programme (ASDSP), Annual work plan and budget. June, 2015.

Mugonola, B., Ajok, W., \& Ongeng, D. (2017). Determinants of market participation for smallholder cassava processors in north and north-eastern Uganda. African Journal of Rural Development, 2(4), 549-563.

Munga, T., Maina, F., Muli, B. M., \& Sila, M. M. (2012). Socioeconomic status of cassava production in major growing districts of Western, Eastern and Coastal regions of Kenya: A baseline survey report for the East African Agricultural Productivity Project (EAAPP). Technical Report No. 7, KARI Mtwapa.

Muricho, G. S. (2015). Determinants Of Agricultural Commercialization And Its Impacts On Welfare Among Smallholder Farmers In Kenya. (Doctoral dissertation), University of Nairobi, Nairobi.

Muriithi, B. W., \& Matz, J. A. (2015). Welfare Effects of Vegetable Commercialization: Evidence from Smallholder Producers in Kenya. Food Policy, 50(15), 80-91. https://doi.org/10.1016/j.foodpol.2014.11.001.

Mutuku, M., Wanda, D., Olubandwa, A., Malin, J., \& Nyakeyo, A. (2013). Commercialization of traditional crops: Are cassava production and utilization promotion efforts bearing fruit in Kenya? Journal of Sustainable Development, 6(7), 48-58. http://dx.doi.org/10.5539/jsd.v6n7p48.

Mwaura, F. (2014). Effect of farmer group membership on agricultural technology adoption and crop productivity in Uganda. African Crop Science Journal, 22(4), 917-927.

Ochieng, J., Knerr, B., Owuor, G., \& Ouma, E. (2015). Agricultural commercialization and household food security: The case of smallholders in the Great Lakes Region of Central Africa. Paper presented at the International Conference of Agricultural Economists, Mila, Italy. (No. 1008-2016-80302).

Olwande, J., \& Mathenge, M. (2010). Market participation among the poor rural households in Kenya. Tegemeo Institute of Agricultural Policy and Development.

Omiti, J., Otieno, D., Nyanamba, T., \& McCulloug, E. (2009). Factors influencing the intensity of market participation by smallholder farmers: A case study of rural and peri-urban areas of Kenya. African Journal of Agricultural and Resource Economics, 3(1), 57-82.

Onya, S., Oriala, S., Ejiba, I., \& Okoronkwo, F. (2016). Market Participation and Value Chain of Cassava Farmers in Abia State. Journal of Scientific Research and Reports, 12(1).

Parveen, S. I., Humaira, K. S., \& Ali, M. (2014). Value addition a tool to minimize post-harvest losses in horticultural crops. Greener journal of Agricultural Sciences, 4(5), 195-198. https://doi.org/10.15580/gjas.2014.5.042914208.

Pingali, P., Khwaja, Y., \& Meijer, M. (2005). Commercializing small farms; Reducing transaction costs. FAO working paper No. 05-08. https://doi.org/10.1079/9781845931858.0267

Pryanishnikov, I., \& Katarina, Z. (2016). Multinomial logit models for the Australian labour market. Australian Journal of Statistics, 32(4), 267-282. https://doi.org/10.17713/ajs.v32i4.461

Quinn, M. A. (2009). Estimating the impact of migration and remittances on agricultural technology. The Journal of Development Areas, 43(1), 199-216. https://doi.org/10.1353/jda.0.0048

Sewando, P. T. (2012). Urban markets-linked cassava value chain in Morogoro rural district, Tanzania. Journal of Sustainable Development in Africa, 14(3), 283-300.

Tambo, J., \& Wünscher, T. (2014). More than adopters: the welfare impacts of farmer innovation in rural Ghana. Selected Paper presented at the Agricultural \& Applied 146 Economics Association's 2014 AAEA Annual Meeting, Minneapolis, MN, July 27-29, 2014.

Tipraqsa, A., \& Schreinemachers, P. (2009). Agriculture commercialization of Karen Hill Tribes in Northern Thailand. Journal of Agricultural Economics Resource, 40(1), 43-53. https://doi.org/10.1111/j.1574-0862.2008.00343.x

World Bank. (2008). Agriculture for Development, World Development Report 2008, World Bank, Washington DC.

Waswa, F., Mcharo, M., \& Netando, G. ( 2009).Enhancing household food and income security in the Nzoia and Mumias sugar-belt, Kenya. Journal of Applied Biosciences, 23, 1406-1415.

Woldeyohanes, T. B., Heckelei, T., \& Surry, Y. (2016). Effect of off-farm income on smallholder commercialization: Panel evidence from rural households in Ethiopia. Journal of Agricultural economics, 48(17), 207-218. https://doi.org/10.1111/agec.12327 
World Bank. (1998). World Development Report-Agriculture for Development. Washington DC, World Bank.

Xing, Z. (2015). Agriculture and Rural Development: The Case of Fiji. (Doctorate dissertation), Massey University, Palmerston North, Newzealand.

Zhou, S., Minde, I. J., \& Mtigwe, B. (2013). Smallholder agricultural commercialization for income growth and poverty alleviation in southern Africa: A review. African Journal of Agricultural Research, 8(22), 2599-2608. https://doi.org/ 10.5897/ajar.111040

\section{Copyrights}

Copyright for this article is retained by the author(s), with first publication rights granted to the journal.

This is an open-access article distributed under the terms and conditions of the Creative Commons Attribution license (http://creativecommons.org/licenses/by/4.0/). 